\title{
PROFILING SECTORAL RISKS OF FOREIGN DIRECT INVESTMENT (FDI) IN AFRICA FOR THE FIRST DECADE OF THE 21 ST CENTURY
}

\author{
Zahné Coetzee (Schutte)* \\ North-West University \\ Zahne_Schutte@cofaceza.com \\ Carike Claassen+ \\ North-West University \\ Carike.claassen@nwu.ac.za
}

Received: March 2015

\author{
Henri Bezuidenhout* \\ North-West University \\ henri.bezuidenhout@nwu.ac.za \\ Ewert Kleynhans@ \\ North-West University \\ ewert.kleyhnans@nwu.ac.za
}

Accepted: September 2015

\begin{abstract}
Despite Africa's strong foreign direct investment (FDI) performance since 2000, the majority of FDI inflows have been directed to a few selected countries. As investors face many risks when investing in developing countries, it is argued that risk perception plays a vital role in the FDI inflows into Africa. This article focuses on the relationship between risk and FDI. A structural equation model is used to analyse this relationship with a dataset of ten risk categories and FDI data from 42 African countries. The study focuses on four sectors, namely metals, automotive, communications and real estate. Overall, results indicate that government effectiveness and legal and regulatory risks produce the biggest concern for investors. The conclusion is that each sector's risk pattern regarding FDI differs. The most important empirical results indicated that African countries should focus more on government effectiveness, stability and transparency to attract the levels of FDI required to stimulate economic growth.
\end{abstract}

Keywords

Foreign direct investment, Africa, risk, structural equation modelling, industries, manufacturing, services

*Ms Z Coetzee (neè Schutte) is a research associate in the School of Economics, North-West University, South Africa.

\#Prof $\mathbf{H}$ Bezuidenhout is an associate professor in the School of Economics, North-West University, South Africa.

+Dr C Claassen is a lecturer in the School of Economics, North-West University, South Africa.

$@$ @rof EPJ Kleynhans is an associate professor in the School of Economics, North-West University, South Africa. 


\section{INTRODUCTION}

FDI inflows into Africa during the first decade of the third millennium (2003-2012) show a sharp increase from previous levels. After a significant growth phase from 2004 to 2008, there was a steep decline until 2010, after which a slight recovery occurred (UNCTAD 2013). This weak performance of FDI inflows into the region as compared with the first decade prompts the question of how African countries broke the negative picture at the beginning of the decade. This paper focuses on the relationship between sectoral risk and FDI in order to establish the picture of whether risk perceptions did indeed affect FDI.

According to the African Economic Outlook (2012), foreign direct investment (FDI) is seen as a major source of growth, as it raises productivity for the whole economy by spreading its effects to other firms and sectors through technology spillovers and increased competition. Subsequent issues have reiterated this view and continue to identify foreign direct investment (FDI) as a major contributor to development in Africa (African Economic Outlook, 2013). Since FDI plays a major role in the promotion of economic development for developing countries, it is extremely important to evaluate how various types of risk influence investment decisions. This article focuses specifically on the sectoral risk determinants for various African countries.

Since 2000, there has been a remarkable increase in FDI flows to developing countries, as they attracted US\$785 billion from 2000 to 2008. At the forefront of the investment trend is the South East Asian (SEA) region, which received $60 \%$ of global FDI inflows in 2009. Even with improved performance, Africa received a mere 11\% (UNCTAD, 2010) of global FDI inflows during 2009. Despite an annual growth rate of $4.9 \%$ between 2000 and 2008 (McKinsey Global Institute, 2010), and several efforts of African countries to increase FDI inflows, Africa is still just managing to sustain development compared to other developing regions. Africa's progress has been inconsistent and lags behind other areas of growth across the world. Chinese investment in Africa is widespread, with 45 of the 53 African nations receiving FDI from China between 2003 and 2008 (UNCTAD, 2007).

While traditional investors focused on investment in North Africa, Chinese FDI to Africa was mostly concentrated in Southern and East Africa. It is also interesting to note that the approach of Chinese firms to do business in Africa differs substantially from the dominant Western approach. The most significant aspect of this is that Chinese firms are less risk averse and also undertake the building of infrastructure in return for access to various natural resources, such as oil and minerals (Sautman \& Yan, 2009).

The much-debated presence of emerging countries, such as China, in Africa has caused concern for traditional investors, with many countries rethinking their approach of FDI to Africa. According to Asiedu (2006), traditional determinants, such as good policies and institutions, are known to be the foundation for attracting FDI to Africa; however, a different approach is needed if Western countries want to keep up with China.

A major aspect of the Western approach to FDI in Africa is its reliance on various credit risk-rating agencies to evaluate the country credit risks according to the financial indicators, balance of payments sheet and other macro-economic indicators. According to Brink (2004), such ratings are often used as a reflection of the overall investment climate of a certain country and not that of a credit rating, the purpose it was designed to fulfil. Country ratings are then mistakenly used for purposes other than those for which they were actually intended. This study aims to review the associated risks for FDI and the approach to it, specifically in Africa and in its individual sectors. 
The rest of this article is organised as follows. The next section presents the background and provides a literature overview of the study. Then the research methods are presented, followed by the results and findings. In the final section, the conclusions and recommendations are discussed.

\section{BACKGROUND AND LITERATURE OVERVIEW}

\subsection{The importance of various types of FDI risk}

There are certain determinants that influence the decision of firms to engage in FDI. Narrowing it further, certain key determinants prevail in Africa. Previous literature indicates that the most significant determinants to Africa are openness to trade, inflation, foreign reserves, natural resource endowments, political freedom and original literacy (Asiedu, 2002; Onyeiwu \& Shretsha, 2004; Naudé \& Krugell, 2007). Most studies focus on souvenir risk (e.g. Bezuidenhout \& Kleynhans, 2015:93), while this is not the only risk curbing FDI in African sectors.

The importance of sectoral determinants and risks regarding the FDI decision is highlighted by Hauser (2005). Hauser (2005) argues that different types of investments are made in different sectors and emphasises this with a study conducted on German and Austrian FDI. He draws the conclusion that investors engaged in the power supply and mining sectors are likely to enter the market by an acquisition (merger) of an existing firm. Firms investing in the manufacturing or services sectors will enter the market via a Greenfield investment due to the mentioned differences. Greenfield FDI entails a new venture that requires new operational facilities to be established.

Since developing countries have been attracting a substantial amount of FDI inflows, which is beneficial for their economic growth and development, it is very important to understand how risks of various types act as constraints to the flows of such investment.

According to White and Fan (2006), different levels of risks exist for various countries, sectors and industries. A firm will engage in FDI if the given level of risk is acceptable. The most relevant risks are global, country, industry and enterprise risk. It is important to take into account that there is a considerable level of overlap between the levels of risk and different types of risk in order to quantify these risks in an empirical evaluation.

The way in which risk is perceived is a significant determinant of FDI. It is therefore important for investors to identify, estimate and assess the relevant risk in order to make an appropriate decision regarding FDI. Risks can be classified in numerous ways, each reflecting a particular focus of interest. In this study, risk will be classified according to the previous discussion that reflects the relationship between risk and FDI at a sectoral level.

\subsection{Africa-specific determinants}

There has been a substantial increase in FDI in developing countries since the first decade of the $21^{\text {st }}$ century commenced, and while Africa did not initially benefit from the boom, the picture is starting to change. McKinsey (2010) highlights the continent's achievement in his paper 'Lions on the move: the progress and potential of African economies'. In 2008, Africa had a collective GDP of US\$1.6 trillion, there have been 316 million new mobile users since 2000, 52 cities have more than one million people each and the continent contains $60 \%$ of the world's uncultivated arable land. Although the region has rebounded well from the global economic and financial crisis, the 
path to recovery was hampered by the image of uncertainty and instability in the political arena (Goldstein, 2004). The political turmoil of North and West Africa, most notably in Libya and the Ivory Coast, is an illustration of how economies are brought to a halt if political instability reigns in a country. Goldstein (2004) supports this view by stating that Africa's perceived risk is a factor that negatively influences FDI to the region.

Asiedu (2002) is of the opinion that another reason for the poor FDI flows into Africa is because of the continent's approach to attracting FDI. She argues that policies implemented in other developing regions have not been successful in Africa. This suggests that Africa has a different set of factors that determine FDI inflows. While a high return on capital and sufficient infrastructure in developing countries are necessary to attract FDI, these determinants are not significant in Africa. Openness to trade seems to be important for both developing countries and the African region.

Ngowi (2001) found that FDI to African countries is influenced by a number of significant determinants. These determinants include human capital, openness to trade, competitiveness, macro-economic indicators, political stability, transparent financial markets and natural resources.

Morisset (2002) found that an environment conducive to business and investment attracts more FDI to African countries than large markets or natural resource endowments. Liberal investment policies along with strong growth now become important determinants for African countries.

Like Goldstein (2004), Jenkins and Thomas (2002) also state that low FDI into Africa is attributable to an 'African image'. The authors conclude that sound economic policies and political stability will improve FDI to the region. According to Naude and Krugell (2003), FDI inflows to Africa generally depend on inflation, good governance, investment, government consumption and literacy.

In another study conducted by Asiedu (2006), it was established that policies to improve economic stability, the availability of natural resources and the size of the domestic market are important factors to attract FDI. Onyeiwa and Shrestha (2004) indicate that the inflation rate, economic growth, foreign reserves, openness and natural resources play a significant role in African countries' ability to promote FDI. Contrary to other studies, the authors conclude that political rights and infrastructure do not have an impact on FDI inflows.

In summary, the literature identifies the key FDI determinants to Africa as openness to trade, inflation, natural resource endowments, political freedom, literacy and the implementation of economic policies.

From the discussions above, it can be concluded that although traditional FDI determinants are present in Africa, the effect is less significant than in developing countries. This is attributed to various factors, such as slow economic reform, closed trade policies and, most importantly, the perceived image of Africa that is a result of an unstable political arena. All these factors are linked to a high-risk perception, as will be discussed in section 2.4. This finding highlights the relevance of establishing the relationship between risk and FDI in Africa in order to indicate whether the authors are correct in their assumption of 'image' being the problem. 


\subsection{Sectoral determinants for FDI in developing countries}

Although much literature exists on FDI in general, specific research on the determinants on a sectoral level is limited. Previous studies at sectoral level for developing countries are limited and will be investigated in the current study to establish an FDI risk framework for Africa.

Blackman and Wu (2002) conducted a study on the determinants of FDI in the Chinese energy sector. They found that government policies, the approval process for FDI projects, regulatory environment and the risk of default on energy purchase contracts are the most important institutional barriers.

According to Tsen (2005), good education, an established infrastructure, a large market and a healthy current account balance are vital determinants to attract FDI to Malaysia's manufacturing sector. Similarly, Dhanini and Hasnain (2002) found that, in the Indonesian manufacturing sector, low labour costs, good education, adequate infrastructure and policies promoting FDI are key factors to attract FDI.

Kolstad and Villanger (2008) established the determinants of FDI for the services industry by using industry-level FDI data from 57 countries. The authors found institutional quality and democracy to be more important determinants than investment risk and political stability. Democracy is a significant determinant in developing countries, while institutional quality is also important to high-income countries. They also concluded that FDI in the services sector is market-seeking and is not affected by trade openness.

Riedl (2009) conducted a study based on FDI data for eight new EU member states classified as transitional economies. He also found that FDI into the services sector is market-seeking, while FDI in the manufacturing sector is driven by international competitiveness measured by labour costs.

Resmini (2000) conducted a study for the Central and Eastern European countries (CEદC) to determine FDI patterns in various sectors and found that FDI inflows to science-based and capital-intensive sectors are influenced by the host country's progress towards a market economy. Trade openness seems to be significant only in traditional sectors and the proximity to Western Europe particularly influences FDI inflows for the science-based and capital-intensive sectors.

As stated earlier, literature regarding the determinants for sectoral level is not only limited, but differs in terms of research methods used, sample size, periods covered and variables used. In general, literature suggests that there seems to be different determinants for various sectors. Strong sectoral effects on FDI suggest that by looking at risk at a sectoral level, a more relevant foundation can be established for the relationship between risk and FDI.

\subsection{Aspects of risk theory focusing on FDI}

Despite challenges such as the global financial crisis in 2008/2009 and, more recently, the negative image due to political upheaval in North Africa, the African continent was a growth hotspot in 2011, with a $24 \%$ increase in FDI projects (FDI Intelligence, 2013). Even with obstacles such as inadequate infrastructure, corruption and conflict, investors remain hopeful of an African renaissance (Creamer, 2012). Foreign investors are confronted with a certain 'African image' of instability and uncertainty. Goldstein (2004) finds that Africa's perceived risk negatively 
influences FDI inflows. This follows Ernst and Young's (2012a) opinion that the perception gap hampers investment from those who are not yet doing business in Africa.

Despite the gap between its actual and perceived risk, Africa does offer opportunities for those willing to invest, with the continent being home to six of the ten fastest-growing economies since 2000 (Creamer, 2012).

This forces a re-evaluation of the way risk is perceived and a careful evaluation of the manner in which risk influences investment decisions. Consequently, investment in Africa and its associated risks will need to be viewed through a completely different lens.

\subsection{Studies pertaining to sectoral risks}

White and Fan (2006) are of the opinion that risk differs significantly by country, sector and industry. Since FDI inflows to the African region have increased substantially, it is important to understand how various risks constrain investments. Although FDI increased significantly, FDI inflows also differed significantly between sectors and this highlights the fact that after the investment decision is made risk still affects the scale and location of the investment. Furthermore, multinational corporations will invest only if the level of risk is acceptable. Drawing from this, it may be concluded that risk perception plays a major part in investment decisions as well as location decisions.

According to Balmelli (2010), the biggest challenge businesses face is the perceptions that clients have of Africa. Africa has the largest gap between perceived and actual investment risk when compared to other emerging countries (Ernst \& Young, 2011). In order to minimise this gap, a thorough understanding of both the perception and reality of investment is needed in Africa.

Literature on the African continent is, however, limited. Studies conducted on other developing countries were investigated in order to create a theoretical framework for Africa.

Using cross-country data for the period 1981 to 1999, Alfaro (2003) studied the benefits of FDI for the primary, manufacturing and services sectors and analysed the growth impact for the host country. The author found that economic growth and other benefits for the host country depend on the sector into which FDI flows.

Resmini (2000) conducted a study on the sectoral determinants of FDI in Central and Eastern Europe. The study used data from 12 host countries over the period 1990 to 1995 and focused on the manufacturing sector. The author explains that the observations have been divided into homogeneous sectors, such as scale-intensive, high-tech and traditional, in order to establish the differences and similarities between industrial sectors. Although data is limited, Resmini (2000) concludes that the results indicate that sector-specific risks can affect FDI distribution of European firms in the manufacturing sector.

Kolstad and Villanger (2008) used panel data to examine the determinants of FDI flows in the services sector. The study was conducted using data from 57 countries, including developed, transition and developing countries, for the period 1989 to 2000. The authors conclude that institutional quality, democracy, and market size are significant determinants. Services, being non-tradable, are unaffected by a host country's trade openness.

Kinoshita's (2011) results indicate that market size, infrastructure, trade integration and a skilled labour force contribute to more FDI in the tradable sectors. The author used data from 15 
Central Eastern and South-Eastern European countries over the period 2000 to 2007 to determine whether FDI inflows to non-tradable sectors contributed to external balances.

Walsh and $y_{u}(2010)$ analysed various determinants of emerging and developed economies using a dataset that distinguishes between primary, secondary and tertiary sector FDI flows. The authors found that secondary and tertiary sectors are influenced in different ways by country income levels, exchange rate valuation, financial depth, school enrolment, judicial independence and labour market conditions. The primary sector showed little dependence on the abovementioned determinants.

In a study conducted on the perception risk of renewable energy in North Africa, the authors found that the barriers to FDI in this sector are regulatory, political and force majeure (which includes terrorism). Various stakeholders were interviewed to assess how perceived risk influences investment in renewable energy projects in North Africa (Komendantova et al., 2012). The authors concluded that in order for the region to attract more FDI, more attention should be paid to a stable enforceable regulatory environment.

In summary, these studies indicate that there is a strong sectoral behaviour of risk and FDI and that no 'one glove fits all' approach can be taken. The next section provides a brief discussion on the sectoral trends in Africa for Greenfield as well as merger and acquisition (M\&A) investments.

\section{SECTORAL TRENDS IN AFRICA}

Ernst and Young's Africa Attractiveness Survey (2011) on FDI projects in Africa indicates that the region is high on the agenda of global investors, with $43 \%$ of respondents already investing in Africa. When confronted with the FDI decision, a firm will either enter the market via a Greenfield investment or by merging with an existing firm. The level of uncertainty or risk and technological advances of a firm offer an explanation as to why one mode of investment is preferred above another (Hauser, 2005).

UNCTAD (2012) cited that cross-border mergers and acquisitions (M\&As) increased by $53 \%$ in 2011 to US\$526 billion, driven by a rise in the number of projects. While higher levels of FDI inflows to developing and transition economies can be attributed to Greenfield investments, the growth in developed regions is spurred on by large M\&A projects. Greenfield investment projects were responsible for US\$904 billion in 2011 and continue to retain a significantly higher level than M\&As, as was the case since the financial crisis of 2007/8 (UNCTAD, 2012).

The current study chose metals, the automotive industry, communications and real estate sectors as representative of African economies to analyse sectoral risk to FDI. FIGURE 1 shows that the number of real estate projects in Africa surpasses the number of any of the other projects in the sectors, because the deals tend to be quite significant. Real estate projects are also more volatile, closely following the trend of global FDI flows, peaking and dropping at corresponding times. Communications experienced very low levels since 2003; nonetheless, inflows into this sector peaked at US\$8 billion in 2009. The boom in communications can be attributed to the increased FDI inflows experienced by Africa as a continent due to higher growth rates. Greenfield investment projects for metals have fluctuated around an average of US\$2billion maximum and US\$1billion minimum for the past eight years. According to Ernst and Young (2012b), the volatility and uncertainty regarding the global economy will continue through 2012, but the metal industry grew and there will be an increase in projects. The automotive sector has not had the same levels of investment compared to the other three sectors, but a steady increase can be noted from 2009. 


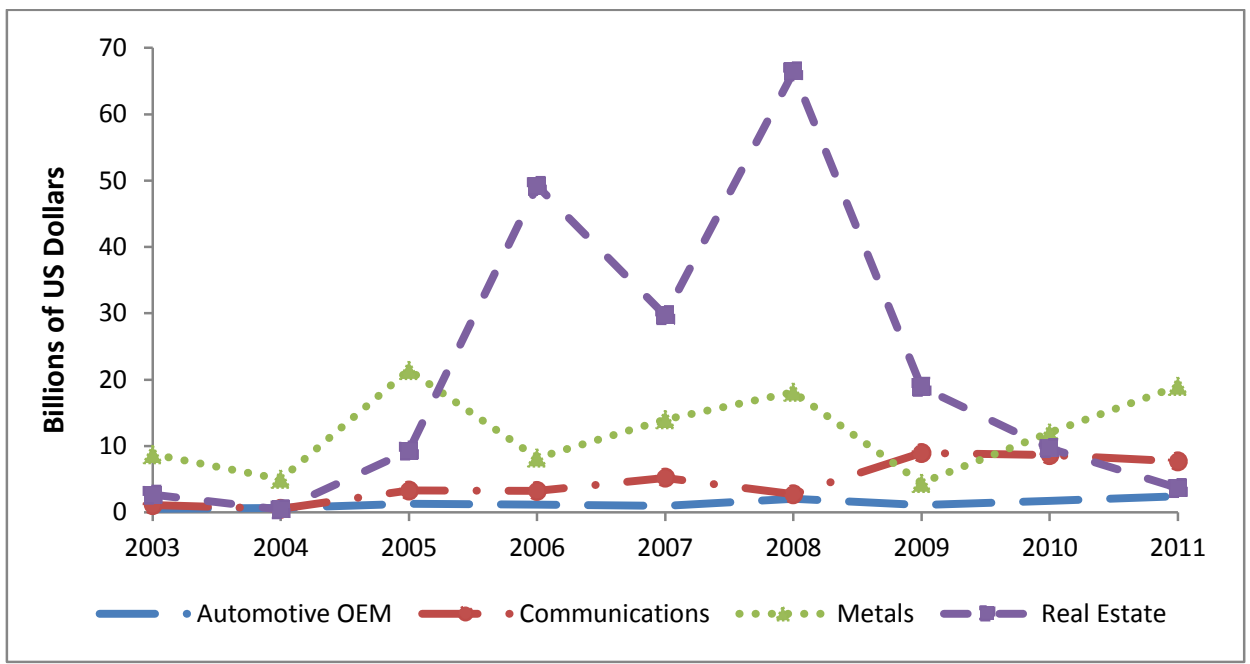

FIGURE 1: Greenfield FDI inflows - Africa

Source: fDiMarkets Database (2013)

On closer investigation of the fDi Markets Database, the following can be concluded regarding Africa's real estate sector. The North African region accounts for the top half of the countries attracting investment. Djibouti, Sudan and the Congo (DRC) also receive a number of projects. Source countries are mainly located in the Middle East (UAE, Bahrain, Qatar), but investments from China are also rising. Switzerland and Luxembourg bring up the rear of the top investors, with nine projects each, mostly across North Africa.

Leading the way in the communications sector from 2003 to 2011 were the United Arab Emirates (UAE), France, the UK, South Africa, China and Finland, with investment projects in Nigeria, South Africa, Uganda, Zimbabwe, Mauritius and Ethiopia (fDi Markets, 2013). The only suitable data available extends only until 2011. More data follow-up studies should continue on these aspects. The main companies include the MTN Group, SEACOM, Zain and Vodafone. The Finnish company, Nokia, has several projects in Africa, with projects based in Egypt, Uganda, Nigeria and Ghana.

Greenfield Metal's investment projects from 2003 to 2011 were aimed at South Africa, Ghana, Congo (DRC), Namibia and Niger. Source countries comprise Canada, Australia, the USA, the UK, China, and the UAE. Luxembourg and Israel stood out, with ArcelorMittal and Engellnvest as the respective companies undertaking investment projects (fDi Markets, 2013).

In the automotive industry, South Africa, Ethiopia, Sudan, Senegal and several North African countries served as destination countries. A noteworthy source country is Iran, with several projects in Algeria, Egypt, Senegal and Sudan. Top companies investing included Nissan, China Motor Corporation, BMW, Iran Khodro Industrial Group (IKCO) and Tata.

FIGURE 2 shows a sectoral distribution of mergers and acquisitions (M\&As) in Africa from 2003 to 2011. It is striking that the real estate and communication sectors have had similar trends up until 2008. Much like Greenfield investment, M\&A investment for the metal sector has fluctuated heavily, with a recent downward trend noted, which is in stark contrast to the upward trend for Greenfield projects. Similarly, the automotive sector has attracted significantly lower levels than that of the other sectors for both Greenfield and M\&As. 


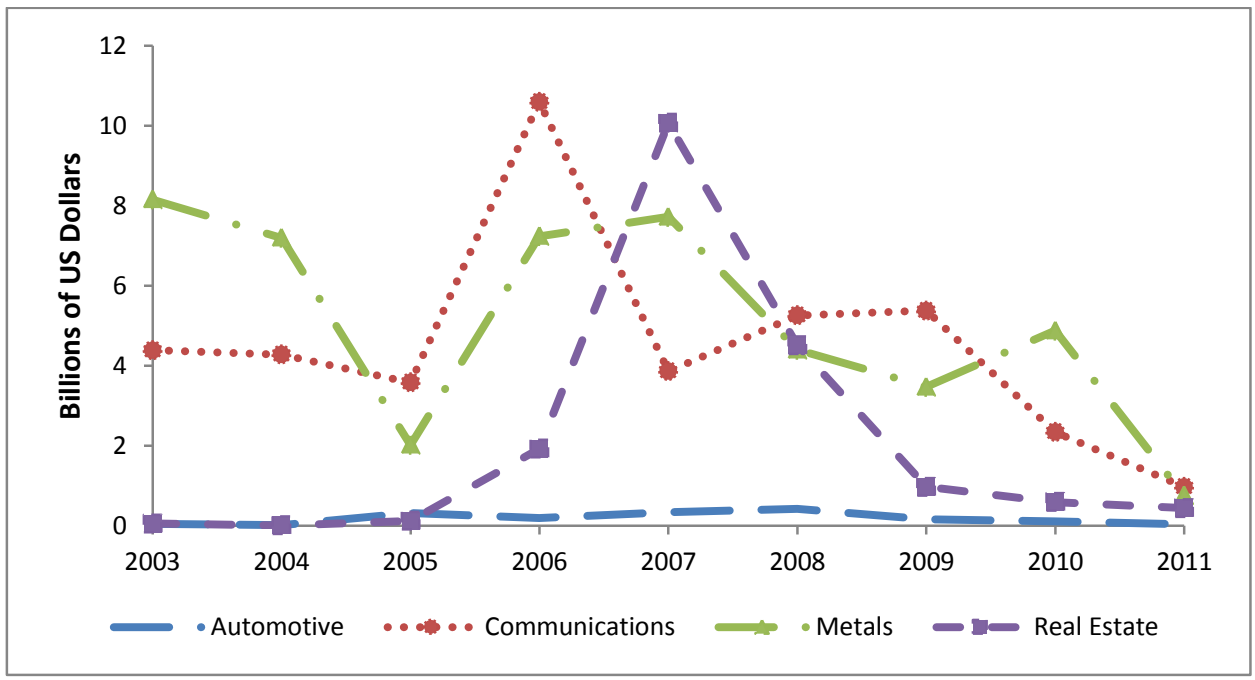

\section{FIGURE 2: M\&A FDI inflows - Africa}

Source: ZephyrDatabase (2013)

Using Bureau van Dijk's (2013) Zephyr database, M\&A projects were analysed. Yet again, the North African region plays a prominent role as an investment destination for real estate. Also noteworthy is that Zimbabwe is an important destination, as well as a source country. The Zimbabwean-owned Pearl Properties has one of the largest M\&A projects in Africa, with a project value of US\$4.329 billion. The project offers the management of real estate on a fee or contract basis and is based in South Africa. Other source countries include Switzerland, South Africa, the Virgin Islands and Ecuador.

M\&A investment projects in the communication sector display similar destination countries as Greenfield investments, but unexpectedly include Sudan, Mali and Burkina Faso. The Netherlands, Nigeria, Egypt, the United Kingdom and France are the primary source countries. The main investing companies comprise the French company Vivendi, Vodafone Group Plc (UK) and Tecom Investments, which is based in the UAE.

Investment projects into the metal sectors were focused on South Africa, Ghana, the DRC, Namibia and Egypt, similar to the Greenfield projects. Brazil made a sizeable investment in Guinea in 2010; Korea undertook a mining investment in the mining of other non-ferrous metal ores in 2006 in Madagascar; and Bermuda has various mining projects across the African continent.

Drawing on previous literature and comparing it to the data discussed, it can be seen that FDI to Africa is on the increase, with mostly developed countries as the main source of investment. Having said this, it is noteworthy to mention that there are several developing countries that have started to play a part, including the likes of China, South Africa, India, Nigeria and Brazil. 


\section{RESEARCH METHOD}

\subsection{Specific sectors chosen}

Specific sectors were chosen to represent Africa because of Africa's unique risk profile and the variation between its sectors. Metal was chosen to represent the primary sector, the automotive industry will represent the manufacturing sector and communications will represent the services sector. Large-scale projects were undertaken in the real estate sector and this will be a representation of the primary, manufacturing and services combined. Though this approach might be considered somewhat arbitrary, the data does not allow for further disambiguation.

\subsection{Risk rating and FDI inflows: data description}

The current research utilised structural equation modelling (SEM) due to Africa's unique problems regarding available data figures. Not all African countries receive FDI in every sector each year. This led the researchers to consider the data from an observation-based population perspective rather than from a time series perspective, as regular econometric techniques would be inadequate due to data limitations. There would be too many 'gaps' in the data due to missing values if standard econometric techniques are used, and the SEM methodology offered a unique way to analyse the research question as an observation-based population technique that allows for factor analysis and identification of unobserved variables such as risk.

The fDi Markets database is the only database that offers specific sectoral and industry information on FDI, especially for the African continent ( $E$ rnst \& Young, 2012). Data is available on a deal-by-deal basis and the period 2003 to 2012 was chosen. This level of data, combined with the reality of African data, motivated the use of SEM modelling.

To provide a scope of the different risks pertaining to international transactions, data from the Economist Intelligence Unit ( $(I U)$ was analysed. In the analysis of the $\varepsilon I U$, the ten aggregated risk indices were used, namely financial, foreign trade and payments, government effectiveness, infrastructure, labour market, legal and regulatory, macro-economic, and political stability risk. These indices are aggregate indices that contain detailed information on all operational risk aspects. TABLE 1 provides a brief overview of the breakdown of the $\varepsilon I U$ indices.

TABLE 1: Economist intelligence unit operational risk indicators

\begin{tabular}{lll}
\hline \multicolumn{1}{c}{ Financial risk } & Government effectiveness risk & \multicolumn{1}{c}{ Labour market risk } \\
\hline Devaluation risk & Policy formulation & Trade unions \\
Depth of financing & Quality of bureaucracy & Labour strikes \\
Access to local markets & $\begin{array}{l}\text { Excessive bureaucracy / red- } \\
\text { tape }\end{array}$ & Labour laws \\
Marketable debt & Vested interests / cronyism & Skilled labour \\
Banking sector health & Corruption & Specialised labour \\
Stock market liquidity & Accountability of public officials & Meritocratic remuneration \\
\hline
\end{tabular}




\begin{tabular}{|c|c|c|}
\hline $\begin{array}{c}\text { Foreign trade \& } \\
\text { payments risk }\end{array}$ & Political stability risk & Security risk \\
\hline Trade embargo risk & Social unrest & Armed conflict \\
\hline Financial crisis & Orderly transfers & Terrorism \\
\hline Discriminatory tariffs & Opposition stance & Violent demonstrations \\
\hline Excessive protection & Excessive executive authority & $\begin{array}{l}\text { Hostility to foreigners / private } \\
\text { property }\end{array}$ \\
\hline Capital account & International tensions & Violent crime \\
\hline $\begin{array}{l}\text { Current account } \\
\text { convertibility }\end{array}$ & & Organised crime \\
\hline Capital controls risk & & Kidnapping / extortion \\
\hline Infrastructure risk & Legal \& regulatory risk & Macro-economic risk \\
\hline Port facilities & Fairness of judicial process & Exchange rate volatility \\
\hline Air transport facilities & Enforceability of contracts & Recession risk \\
\hline $\begin{array}{l}\text { Retail and distribution } \\
\text { network }\end{array}$ & Speediness of judicial process & Price instability \\
\hline Telephone network & $\begin{array}{l}\text { Discrimination against foreign } \\
\text { companies }\end{array}$ & Crowding out \\
\hline Road network & Confiscation/expropriation & Interest rate volatility \\
\hline Power network & Unfair competitive practices & \\
\hline Rail network & $\begin{array}{l}\text { Protection of intellectual } \\
\text { property rights }\end{array}$ & Tax policy risk \\
\hline \multirow[t]{4}{*}{ IT infrastructure } & Protection of private property & Stable regime \\
\hline & Integrity of accounting practices & Discriminatory taxes \\
\hline & Price controls & Level of corporate taxation \\
\hline & & Retroactive taxation \\
\hline
\end{tabular}

Source: Economist Intelligence Unit (2013)

EIU data is available for 44 African countries from 2006 and for 22 from 2003. This limitation further hampers the analysis, as countries for which no data exists are excluded from the analysis. Due to the limited availability of suitable data, countries excluded from the empirical study include Congo (DRC), Liberia, Sierra Leone, Djibouti, Comoros, Guinea Bissau, Somalia, Mauritania, Mali, Central African Republic and Niger. 


\section{THE RESEARCH SPECIFICATION}

\subsection{General specification}

In answering the research question concerning risk factors, significant for FDI in Africa, of the automotive, communication, mining and real estate sectors, structural equation models (SEMs) were applied, as explained above. Standard econometric techniques would not be adequate to accommodate the data limitations discussed in FDI in country and sector-specific sets, while SEM modelling served this study uniquely.

In order to determine the correlation between risk and FDI, the sample population used is all the Greenfield FDI deals for the four sectors. Instead of using annual data, this study focuses on the information per FDI deal. The value of investment projects into different sectors was measured against risk ratings. The study therefore investigates whether the various risk category factors have an influence on the inflows of FDI to African countries. The process firstly does a factor analysis on the risk factors in the population of deals to determine an unobserved joint risk variable and then regresses the unobserved risk variable on the value of FDI.

\subsection{Structural equation modelling}

Structural equation modelling (SEM) is a general statistical modelling technique used to establish relationships among variables. SEM is widely used in the social sciences and results in many different opinions and criteria for acceptability. It is regarded as a confirmatory technique in that it tests models quantitatively that are conceptually derived beforehand. Consequently, SEM allows for the testing of theoretical specification and is therefore theory-driven and not datadriven like normal regression. SEM is a combination of factor analysis and a series of multiple regressions. In this sense, SEM allows for the simultaneous testing of both the measurement model and the structural relationships in the model. The measurement model specifies the relationships between variables and factors (Arbuckle, 2011).

SEM modelling was considered superior to other multiple regressions, because the factors and variables can be correlated (as theory states they are), which cannot be done in usual regression analysis. Another advantage is that SEM allows for multiple dependent variables or a single dependent variable, whereas single regression analysis is restricted to the use of only one dependent variable. SEM should also not be confused with Systems of Equations Models used in econometrics to join numbers of single equations models into a system. The sub-group ability allows for the determination of the relationships between variables. Via the interpretation of the measurement models, the extent to which the theory is supported by the data is examined.

The measure of the degree of fit of the models that are used is important. The two main classes of model fit indices are the absolute fit and the relevant fit indices. Within these two classes, there are several indices that are used in SEM literature. A brief discussion of the main types follows.

The absolute fit indices describe the ability of the model to reproduce the covariance matrices. It is critical to examine the model fit indices, as they are useful to test certain hypotheses, especially those involved in the comparison of different models evaluated with the same data. The types of indices associated with the absolute fit comprise model chi-square $\left(\chi^{2}\right)$, the minimum discrepancy for the model based on chi-square (CMIN), root mean squared error of approximation (RMSEA) and goodness of fit (GFI). These indices provide a clear perspective on the ability of a model to duplicate the covariance matrices. Two models are compared by 
evaluating absolute fit as well as relative fit. Relative fit of the model is established by comparing the theoretical model and the baseline model. The baseline model has a standard specification with the assumption that no relationships exist among the variables. The relative fit of the model will indicate whether the estimated model is a better one than one with no correlation between variables.

The model's chi-square tests the hypothesis that the observed and implied covariance matrices are equal. A non-significant chi-square value $(p>.05)$ will indicate a good-fitting model, suggesting that there are few discrepancies between the observed and implied covariance matrices. The RMSEA looks at the average size of residuals; therefore, smaller values indicate a better-fitting model. Values that are less than 0.10 indicate an acceptable fit, whereas values less than 0.05 indicate a good-fitting model (Arbuckle, 2011).

The indices of relative fit compare a theoretical model with a baseline model. The baseline model specifically considers a model with no relationships among variables. Therefore, these fit indices determine whether the model specified is better than a model with no relationships between variables. The most commonly reported relative indices are the normed fit index (NFI), incremental fit index (IFI), the comparative fit index (CFI), Bolen's relative fit index (RFI) and its derivative, the Tucker-Lewis coefficient or index (TLI). Their values will range from 0 to 1 , for all three of these fitted indices, and generally those values that are greater than 0.9 suggest a goodfitting model.

\subsection{Model specification}

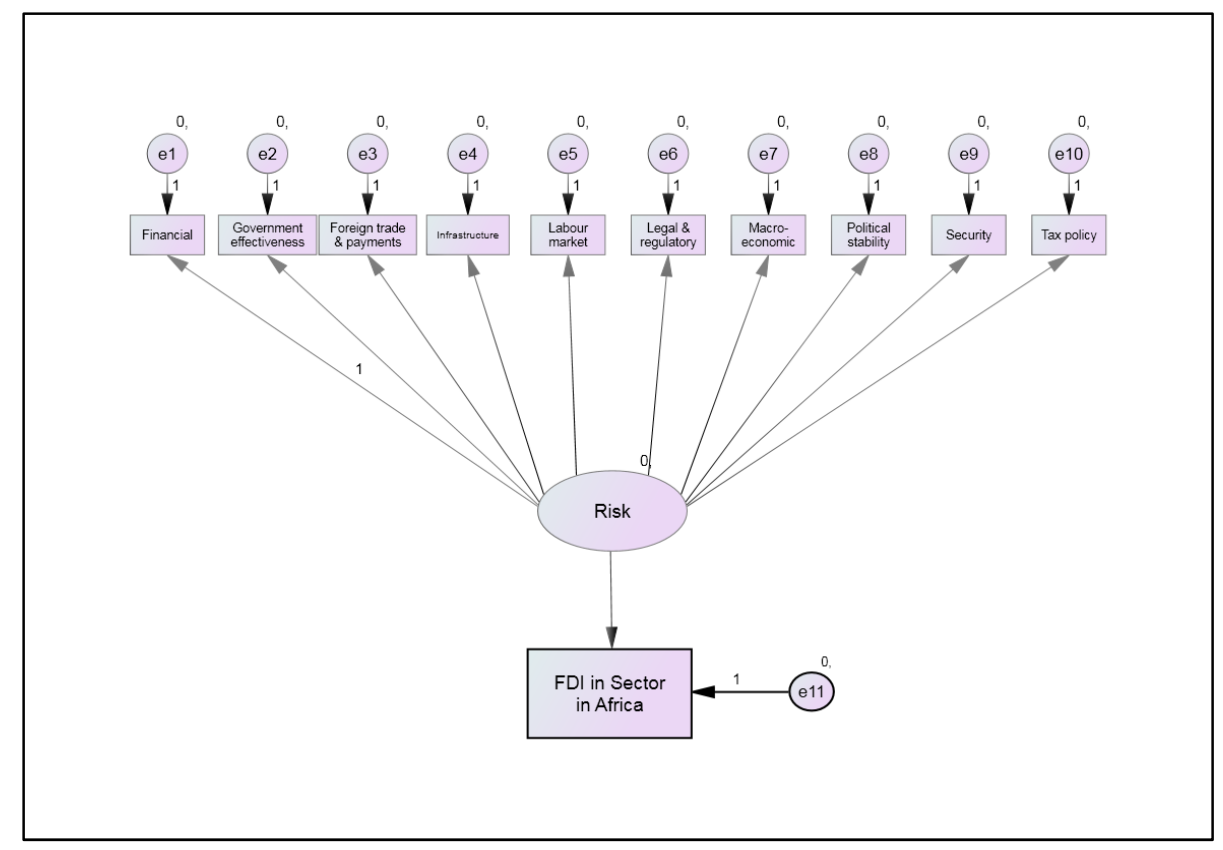

FIGURE 3: Structural equation model specification

Source: Own specification based on theoretical basis 
From our initial literature review, a strong case was made for investigating the differences in sectoral risks on FDI inflows. By using the Economist Intelligence Unit operational risk classification, we identify the unobserved risk variable for each sector and determine which of the risk categories are significant for the specific sector.

Three different types of SEM specifications exist: these are confirmatory factor analysis (CFA), path analysis where observed variables are used, and path analysis where unobserved (latent) variables are used. The current study uses the CFA method because of its more deductive nature. It follows a more logical approach due to its bottom-up strategy, which indicates that the conclusions are reached empirically. A top-down approach will alternately be used where a conclusion is derived beforehand, based on theory. The SEM is estimated based on the theoretical model of the risk factors that have an influence on FDI. The sectoral model forms the empirical part, and depending on the model's goodness of fit, conclusions are made based on the empirical results (Arbuckle, 2011).

The graphical SPSS Amos specification of the model is shown in FIGURE 3. The different risk categories are used as observed variable, which constitutes the factors of the unobserved risk variable (latent variable) that is regressed against FDI. A combination of factor analysis and regression is used to test the model using SPSS Amos.

\section{EMPIRICAL RESULTS}

\subsection{Results of the general model}

The high CMIN values and low NFI and IFI values provided in TABLE 2 indicate that the various sectors are significantly different and that it is better to fit a separate model for each sector rather than using a general model under which each sector can have a nested model.

TABLE 2: Estimation results for general model

\begin{tabular}{lccccccc}
\hline Model & DF & CMIN & $p$ & NFI & IFI & RFI & TLI \\
\hline Measurement weights & 30 & 243.6 & 0.0 & 0.0 & 0.0 & 0.0 & 0.0 \\
Measurement intercepts & 63 & 635.7 & 0.0 & 0.1 & 0.1 & 0.0 & 0.0 \\
Structural covariances & 66 & 638.6 & 0.0 & 0.1 & 0.1 & 0.0 & 0.0 \\
Measurement residuals & 99 & 2628.1 & 0.0 & 0.3 & 0.4 & 0.2 & 0.2 \\
\hline
\end{tabular}

Source: Authors' calculations

where:

$\mathrm{DF}=$ Degrees of freedom; CMIN = minimum discrepancy for the model based on chi-square; $p=$ probability; $\mathrm{NFI}=$ normed fit index; $\mathrm{IFI}$ = incremental fit index; $\mathrm{RFI}=$ Bolen's relative fit index; $\mathrm{TLI}=$ Tucker-Lewis coefficient; RMSEA = root mean squared error of approximation; and PCLOSE = close to exact fit measure. 


\subsection{Sector comparison}

Three of the measurement models show an insignificant relation between risk and FDI. This reveals an insignificant relationship between the risk rating of a country and the FDI amount invested. It was noted above that researchers, such as Brink (2004), had already expressed the need for better measurers of specific risks. The difference in the results obtained from the different sector models suggests a significant difference regarding the risk profile of investment observations. The underlying covariance and correlation structure of the observation-based FDI data allow the FDI figures to influence the risk factors that make up the unobserved risk factor - which highlights the most significant finding of this study.

TABLE 3: Summary of SEM estimations for the different sectors

\begin{tabular}{lcccccc}
\hline Metals & CMIN/DF & NFI & IFI & CFI & RMSEA & PCLOSE \\
\hline Default model & 3.9 & 0.972 & 0.979 & 0.979 & 0.101 & 0.003
\end{tabular}

\begin{tabular}{lcccccc} 
Automotive 0EM & CMIN/DF & NFI $\Delta$ & IFI $\triangle$ & CFI & RMSEA & PCLOSE \\
\hline Default model & 2.723 & 0.958 & 0.973 & 0.973 & 0.099 & 0.009 \\
\hline Communications & CMIN/DF & NFI $\Delta$ & IFI $\Delta$ & CFI & RMSEA & PCLOSE \\
\hline Default model & 3.520 & 0.967 & 0.976 & 0.976 & 0.093 & 0.003 \\
\hline Real Estate & & & & & & \\
\hline Default model & CMIN/DF & NFI $\Delta$ & IFI $\triangle$ & CFI & RMSEA & PCLOSE \\
\hline
\end{tabular}

Source: Authors' calculations

A summarised overview of the estimation results for the different sectors is provided in TABLE 3 . The results are markedly different from the aggregate model, with the estimation indicating significant and good fit. CMIN/DF is the primary measure of fit. It represents the minimum discrepancy of the model divided by the degrees of freedom. Although there is no set criterion, the general rule is that below 5 is a 'good fit' and below 3 an 'extremely good fit'. All the sectors are below 5 and automotive and real estate are below 3 . The NFI, IFI and CFI values as mentioned before should be close to 1 . In all cases, they are above 0.95 . For the real estate sector, they are above 0.99 . These results validate the interpretation of good fit.

The root mean squared error of approximation (RMSEA) values are 0.1 or below and the closeness to the exact fit measure values (PCLOSE) are below 0.05 , except for real estate. The high value for real estate is attributed to population size, as this sector has the least number of observations and the PCLOSE measure is closely related to population size.

A summary of the estimated significant risk factors is provided in TABLE 4 . The first section of the table lists the significant factors of the unobserved risk variable and their standardised effects. Significance is indicated by a result of 0.7 or above. From these results, one can conclude that there is a distinctive difference in risk factors for each sector. 
TABLE 4: Factors analysis: significant risk factors

\begin{tabular}{|c|c|c|c|c|}
\hline & Metals & Automotive & Communication & Real estate \\
\hline \multicolumn{5}{|c|}{ Significant risks factors } \\
\hline Legal and regulatory & 0.93 & 0.96 & 0.99 & 1.00 \\
\hline Financial & 0.76 & 0.91 & 0.79 & 0.73 \\
\hline Government effectiveness & 0.97 & 0.89 & 0.90 & 0.81 \\
\hline Tax policy & 0.82 & 0.78 & 0.74 & 0.80 \\
\hline Political stability & 0.77 & 0.69 & 0.67 & - \\
\hline $\begin{array}{l}\text { Foreign trade and } \\
\text { payments }\end{array}$ & 0.80 & 0.75 & 0.77 & - \\
\hline Infrastructure & - & 0.77 & 0.74 & - \\
\hline \multicolumn{5}{|c|}{ Total risk to FDI } \\
\hline & Insignificant & Negative 0.15 & Insignificant & Insignificant \\
\hline
\end{tabular}

Source: Authors' interpretation

Note: Standardised factor weights above 0.7 indicate a significant factor

The bottom part of the table is the regression of the unobserved risk variable on FDI. The results are in general insignificant or slightly negative. The FDI variable constitutes the actual dollar value and one can conclude that the actual investment amount is unrelated to risk. The significance in the risk factors in the sample of FDI deals per country per year does, however, reflect that risk is a significant factor in the decision on whether to invest or not.

The study examined the difference in risk factors for the various sectors that were tested. Risk factors shown in TABLE 4 to be insignificant are the political stability factor, especially for the real estate sector, and in some cases, the infrastructure risk factor. The most significant risks tend to be the legal and regulatory, and government effectiveness factors. These findings also link to the research finding of Goldstein (2004). It can be concluded that there are different risk patterns regarding FDI inflows for Africa.

Bearing this in mind, the results presented lead to a particular conclusion that certain sectors are influenced by specific risk factors, as is indicated in TABLE 4. For the automotive industry, the legal and regulatory, financial and government effectiveness risks are the most significant, which is an indication that the sector leans toward being efficiency-seeking. Risk to FDI is insignificant for the metals industry and the communication sector. FDI inflows for the metals sector tend to be resource-seeking, while FDI inflows for communications are market-seeking. This also links to the research findings of Sautman and Yan (2009) and Hauser (2005), which indicated that the preferred mode and level of FDI links with particular firms' and industries' level of technological advances. The real estate sector is the only sector with an acceptable model fit, and a strong covariance is evident between the financial and tax policy risk. This finding reveals that investment in this sector could be asset and investment tax-driven. 
The study exposed some interesting findings regarding the relationship between risk and FDI in Africa. As more data becomes available, future research will hopefully be able to address the relationship in a much more in-depth manner than has been possible here.

\section{CONCLUSION AND RECOMMENDATIONS}

The objective of this study was to specifically explore, on sectoral level, the relationship between risk and FDI inflows into various African countries. The intention was to determine, with the help of literature and empirical evidence, the effect of risk-rating factors on FDI inflows into various sectors of the economy and whether the effect of these factors was significant. Metals, the automotive industry, communications and real estate sectors were used as representative of African economies to analyse sectoral risk to FDI.

A breakdown of the operational risk indicators into aspects such as financial risk, government effectiveness risk, labour market risk, political stability risk, security risk, infrastructure risk and tax policy risk, among other factors, was initially used to locate specific sectorial risks that are found and that ensure that the focus is not only on sovereignty risk (see e.g. Economist Intelligence Unit, 2013). The empirical investigation applied Structural Equation Models (SEMs), as this method accommodates the data limitations and served the specific study's research question uniquely. SEM is a combination of factor analysis and a series of multiple regressions. SEM allows for the simultaneous testing of the measurement model, the underlying theory and the structural relationships in the model (Arbuckle, 2011). SEM is regarded as superior to other multiple regressions, because the factors and variables can be correlated, it allows for multiple dependent variables and studying sub-groups, and it allows for the determination of the relationships between variables.

This study focused on the African region and posed the question whether a relationship exists between risk and FDI. This study has made four contributions:

- Firstly, it has provided an empirical test of the relationship between risk and FDI inflows and analysed it in a quantitative way. The need for this was already expressed in the theoretical work of researchers such as Hauser (2005). The results indicate that in Africa risk factors differ for the various sectors they were tested against.

- Secondly, a contribution was made to the literature on FDI to African countries. This study also contributed to the relatively small but growing literature on sectoral FDI. Very few studies exist that focus on African FDI, let alone sectoral FDI. Researchers such as Blackman and Wu (2002), Dhanini and Hasnain (2002), Tsen (2005), and Riedl (2009) investigated investment risk for some sectors, as was mentioned above, but their research did not include African countries.

- Thirdly, it added to the relativity of traditional determinants of FDI to Africa. The results showed that certain sectors are influenced by certain risk factors. It can be concluded that traditional determinants, such as those highlighted by Ngowi (2001), provide the overall framework for investment decisions concerning Africa, but a different approach is needed when investing in specific sectors within individual countries.

- Fourthly, the results obtained are of interest to African countries looking to attract FDI through favourable investment policies. African governments need to identify and implement sustainable policies in order to strengthen their investment climate and reduce risk (se e.g. Asiedu, 2002 and Morisset, 2002). These policies and promotions should be 
designed with a focus on each sector or industry's particular risk profile and risk factors affecting investment. Policies could include the reform of tax incentives and innovative financing schemes such as public-private partnerships.

Recommendations for further research include an expansion of the selection of the sectors presented in this study. Research could also be conducted on investment into individual African countries in order to gain an in-depth insight into how risk affects the FDI inflows into particular sectors of specific countries. Country analyses will provide different insights than the general overview that was given in the study.

Many arguments can be made about how this affects the study and the outcome. The fact is, however, that just because certain data does not currently exist, this does not mean that no analysis is possible. Africa cannot wait ten years for adequate data to solve its current needs. A thorough scientific approach to the data that is available will provide an indication of possible trends and form the foundation of future work in this area. As new data becomes available, this kind of analysis should be repeated and, when possible, more advanced techniques should be used.

As for any study conducted on multiple African countries, the main constraint for this study was the availability of adequate data. Although the situation is changing, with more and more international bodies and private entities collecting more specific data, the need still exists for African governments to produce more detailed and transparent data, especially data concerning merger and acquisition (M\&A) projects.

To conclude, the literature review discussed several categories of risks that affect the investment decision, in general and in developing countries in particular. These differences were highlighted by some researchers, such as White and Fan (2006), but the notion has not yet been adequately quantitatively assessed. These risks include financial, operational, regulatory and even cultural risks. The study focused particularly on risks associated with investment in the metals, automotive, communications and real estate sectors. The results showed that legal and regulatory and government effectiveness risks cause the biggest concern for investors. This highlights the importance of stable and predictable regulations as well as a transparent and effective government to ensure continuous FDI inflows. These findings were already expected by researchers, such as Goldstein (2004), although they did not have the adequate instruments to verify this quantitatively. There is a need for African governments to identify policies and procedures that can best reduce regulatory risk in order to stimulate investment. It was shown above that Kolstad and Villanger (2008) found democracy to be an important determinant of FDI to developing countries. Additional efforts to ensure good governance will add to the favourable investment climate. It was also indicated above that researchers such as Goldstein (2004), Ernst and Young's (2012a) and Balmelli (2010) expressed the need to change the negative perceptions concerning investment in Africa. Any progress on reducing these risks could bring benefits for African countries that are looking to increase their levels of FDI.

\section{Acknowledgement}

This article was made possible through funding by $\varepsilon$ conomic Research South Africa (ERSA). 


\section{LIST OF REFERENCES}

African Economic Outlook. (2012). Promoting youth employment. Available:

http://www.africaneconomicoutlook.org/fileadmin/uploads/PAGES-

\%20Pocket\%20Edition\%20AE02012-EN.pdf. (Accessed 16 February 2015).

African Economic Outlook. (2013). Structural transformation and natural resources. Available: http://www.africaneconomicoutlook.org/fileadmin/uploads/aeo/PDF/Regional_Edition/AEO_2013_ THEMATIC_EDITIONS_WEB.pdf. (Accessed 16 February 2015).

Alfaro, L. (2003). Foreign direct Investment and growth: Does the sector matter? Working Paper. Harvard University: Harvard Business School.

Arbuckle, J.L. (2011). IBM SPSS Amos 20 user's guide. Chicago, IL: Amos Development Corporation.

Asiedu, $\varepsilon$. (2002). On the determinants of foreign direct investment to developing countries: Is Africa different? World Development, 30(1), pp. 107-119.

Asiedu, ع. (2006). Foreign investment in Africa: The role of natural resources, market size, government policy, institutions and political instability. The World Economy, 29(1), pp. 63-77.

Bezuidenhout, H. \& Kleynhans, E.P.J. (2015). Implications of foreign direct investment on sovereignty: The Wal-Mart/Massmart merger as illustration. South African Journal of International Affairs. 22(1), pp. 93-110.

Blackman, A. \& Wu, X. (2002). Foreign direct investment in China's power sector: trends, benefits and barriers. Energy Policy, 27, pp. 695-711.

Brink, C. (2004). Measuring political risk: risks to foreign direct investment. Surrey: Ashgate.

Creamer Media. (2012). Gap between Africa's perceived, actual risks spells opportunity. Engineering News, 28 March. Available: http://www.engineeringnews.co.za/article/gap-between-africasperceived-actual-risks-spells-opportunity-2012-03-28. (Accessed 16 February 2015).

Dhanani, S. \& Hasnain, S.A. (2002). The impact of foreign direct investment on Indonesia's manufacturing sector. Journal of the Asia Pacific Economy, 7(1), pp. 61-94.

Economic Intelligence Unit (EIU). (2012). The Economist. Available: https://portal.eiu.com/. (Accessed 16 February 2015).

Ernst and Young. (2011). It's time for Africa: Africa Attractiveness Survey. London.

Ernst and Young. (2012a). Building Bridges: Attractiveness survey. London.

Ernst and Young. (2012b). Global mining and metals transactions - 2011 trends, 2012 outlook. Available: http://www.ey.com/GL/en/Industries/Mining---Metals/Global-mining-and-metalstransactions---2011-trends-2012-outlook---0utlook---striking-the-balance-and-exploringcapital-raising-options. (Accessed 16 February 2015).

FDI Intelligence. (2013). The fDi Report. Global Greenfield investment trend. Lond on: The Financial Times Ltd.

FDI Markets. (2013). Crossborder Investment Monitor. Available: http://www.fdimarkets.com/. (Accessed 16 February 2015).

Goldstein, A. (2004). Regional integration, FDI and competitiveness in Southern Africa. OECD Development Centre Studies. 
Hauser, F. (2005). Country risk and foreign direct investment in transition countries. Inaugural dissertation: University of Munich. Munich. 2005.

Jenkins, C, \& Thomas, L. (2002). Foreign direct investment in Southern Africa: Determinants, characteristics and implications for economic growth and poverty alleviation. CSAE/0xford and CREFSA, London School of Economics.

Kinoshita, Y. (2011). Sectoral composition of foreign direct investment and external vulnerability in Eastern Europe. IMF Working Paper WP/11/123. Washington: IMF.

Kolstad, I. \& Villanger, E. (2008). Determinants of foreign direct investment in services. European Journal of Political Economy, 24(2), p. 518.

Komendantova, N., Patt, A., Barras, L. \& Battaglini, A. (2012). Perception of risks in renewable energy projects: The case of concentrated solar power in North Africa. Energy Policy, 40, pp. 103-109.

McKinsey Global Institute. (2010). Lions on the move: The progress and potential of African economies. London: McKinsey and Company.

Morisset, J. (2002). Foreign Direct Investment in Africa: Policies also matter. New horizons for foreign direct investment, 548, p. 167.

Naudé, W.A. \& Krugell, W. (2003). Developing human resources to attract foreign direct investment in Africa. Management Dynamics, 12(3), pp. 2-12.

Naudé, W.A. \& Krugell, W. (2007). Investigating geography and institutions as determinants of foreign direct investment in Africa using panel data, Applied Economics, 39(10), pp. 1223-1233.

Ngowi, H. (2001). Can Africa Increase its Global Share of Foreign Direct Investment (FDI)?, West Africa Review, 2(2), pp. 1-22.

Onyeiwu, S. \& Shretsha, H. (2004). Determinants of foreign direct investment in Africa. Journal of Developing Societies, 20(1-2), pp. 89-106.

Resmini, L. (2000). The determinants of foreign direct investment in the CદECs: New evidence from sectoral patterns. Economics of Transition, 8, pp. 665-689.

Riedl, A. (2009). Location factors of FDI and the growing services economy. Economics of Transition, 18(4), pp. 741-761.

Sautman, B. \& Yan, H. (2009). Friends and interests: China's distinctive links with Africa. African Studies Review, 50(3), pp. 75-114.

Tsen, W.H. (2005). The determinants of foreign direct investment in the manufacturing industry of Malaysia. Journal of Economic Cooperation, 26(2), p. 106.

United Nations Conference on Trade and Development (UNCTAD). (2007). World Investment Report. Transnational corporations, extractive industries and development, New York: United Nations.

United Nations Conference on Trade and Development (UNCTAD). (2010). World Investment Report Investing in a low-carbon economy. New York: United Nations.

United Nations Conference on Trade and Development (UNCTAD). (2012). World Investment Report Towards a New Generation of Investment Policies. New York: United Nations.

UNCTAD. 2013. World Investment Report 2013: Global Value Chains: Investment and Trade for Development. Geneva: UNCTAD. 
Walsh, J. \& Yu, J. (2010). Determinants of Foreign Direct Investment: A Sectoral and Institutional Approach. IMF Working Paper WP/10/1873. Washington: IMF.

White, C. \& Fan, M. (2006). Risk and Foreign Direct Investment. New York: Palgrave MacMillan. 